\title{
KEKERASAN DOMESTIK \\ TERHADAP PEREMPUAN DAN ANAK \\ DI KABUPATEN LOMBOK TIMUR
}

\author{
Nisfawati Laili Jalilah \\ Dosen fakultas Syariah UIN Matram \\ Email: Nisfawati302412@uinma.ac.id
}

\begin{abstract}
Abstrak
Masalah kekerasan domestik terhadap perempuan dan anak sejatinya telah berlangsung lama. Namun, masalah ini tidak pernah menjadi domain publik. Hal ini disebabkan karena masalah kekerasan domestic dianggap sebagai masalah privat, yang umumnya terjadi dalam keluarga inti. Faktor agama yang kuat serta relasi social dan budaya dalam masyarakat Indonesia, mengakibatkan masalah-masalah kekerasan terhadap perempuan dan anak cenderung dibiarkan menguap dalam ruang tertutup keluarga. Hal ini juga disebabkan oleh keyakinan bahwa mengungkapkan masalah keluarga kepada orang lain sebagai hal yang tabu dibicarakan dengan orang lain. Ini menyebabkan semakin meningkatnya laopran kasus kekerasan domestic terhadap perempuan dan anak. Pada tingkat nasional, jumlah kasus kekerasan terhadap anak dan perempuan meningkat hampir $400 \%$ dalam kurun waktu 20012006. ${ }^{1}$ Hal yang sama terjadi di Provinsi Nusa Tenggara Barat, dimana terjadi peningkatan kasus kekerasan terhadap perempuan dan anak.

Penelitian yang bersetting di Lombok Timur ini mencoba untuk mengupas fenomena kekerasan perempuan. dalam penelitian ini menggunakan penelitian kualitatif atau deskriptif analitis dengan menggunakan pendekatan normatif empiris, dalam hal ini menggunakan pendekatan yang mengacu pada Undang-undang No. 23 tahun 2004. Penelitian ini menghasilkan temuan yang berupa faktor-faktor yang menyebabkan terjadinya kekerasan domestik perempuan dan anak, yaituMasalah keuangan atau ekonomi, Masalah anak, cemburu,salah paham, mau menang sendiri, tidak dapat menahan nafsu dan emosi,mabuk,ada wanita atau laki-laki lain (WIL dan WIL), masalah orang tua, dll.Hubungan atau relasi antara korban dengan pelaku ketika kekerasan itu terjadi yaitu lebih banyak dilakukan orang-orang

${ }^{1}$ Kompas, edisi 8 maret 2006. Tahun 20013.169 kasus, tahun 20025.163 kasus, Tahun 20037.787 kasus, Tahun 200414.020 kasus, dan 2005 meningkat lebih dari 100\% dan mencapai angka 20.391 kasus. Diyakini, angka yang sesungguhnya jauh lebih besar dari ini.
\end{abstract}


terdekat atau dilingkungan keluarga, seperti suami istri, orang tua serta keluarga lannya.

Kata Kunci: Kekerasan Perempuan dan anak, KDRT

\section{A. Pendahuluan}

Akhir-akhir ini kekerasan dalam masyarakat tampak semakin meningkat baik kualitas maupun kuantitasnya. Diantarajenis kekerasan yang terjadi adalah kekersan yang terjadi terhadap perempuan dan anak yang banyak mendapat perhatian karena dampaknya yang luas bagi kehidupan perempuan dan anak serta masyarakat pada umumnya.

Kekerasan jenis ini memiliki akar yang dalam pada faktor budaya yang menempatkan perempuan pada posisi yang timpang dalam hubungannya dengan laki-laki. Hal ini diakui oleh masyarakat Internasional sebagaimana dikemukakan dalam Deklarasi PBB tentang Penghapusan kekerasan terhadap Perempuan. Disebutkanbahwakekerasanterhadap perempuan merupakan perwujudan ketimpangan historis hubungan kekuasaan antara laki-laki dan perempuan. Hal ini mengakibatkan timbulnya dominasi dan diskriminasi terhadap perempuan dan lakilaki. Tindak kekerasan terhadap perempuan merupakan salah satu mekanisme social yang krusial, yang mendorong perempuan dalam posisi subordinasi dibandingkan dengan laki-laki.
Sementara itu system hokum nasional kita baik dari segi substansi, sikap para penegak hokum maupun masyarakatmasihmenganggapbahwa kekerasan terhadap perempuan dan anak dipandang sama dengan jenis kejahatan pada umumnya. Bahkan dalam banyak hal sering sekali aparat penegak hokum dan masyarakat cenderung melihat kekerasan jenis ini sebagai kesalahan korban, baik perempuan maupun anak.

Masalah kekerasan domestik terhadap perempuan dan anak sejatinya telah berlangsung lama. Namun, masalah ini tidak pernah menjadi domain publik. Hal ini disebabkan karena masalah kekerasan domestic dianggap sebagai masalah privat, yang umumnya terjadi dalam keluarga inti. Faktor agama yang kuat serta relasi social dan budaya dalam masyarakat Indonesia, mengakibatkan masalah-masalah kekerasan terhadap perempuan dan anak cenderung dibiarkan menguap dalam ruang tertutup keluarga. Hal ini juga disebabkan oleh keyakinan bahwa mengungkapkan masalah keluarga kepada orang lain sebagai hal yang tabu dibicarakan dengan orang lain. 
Perubahan paradigma akan perlunya mengekspose dan melindungi korban-korban kekerasan domestik, khususnya perempuan dan anak-anak, mengemuka seiring dengan menguatnya perspektif Hak Azasi Manusia (HAM). Bersamaan dengan hal itu, muncul desakan kuat pada Negara untuk melindungi para korban kekerasan domestik. Desakan ini berbuah dengan dilahirkannya Undang-undang No. 23 tahun 2004 tentang Penghapusan Kekerasan Dalam Rumah Tangga. Disamping itu, setiap pemerintah daerah juga diwajibkan membentuk dan mengembangkan system dan mekanisme kerjasama dalam penanganan korban kekerasan dalam rumah tangga (Pasal 13 UU No. 23/2004).

Di Nusa Tenggara Barat, regulasi mengenai perlindungan terhadap perempuan dan anak di atur melalui Perda No.2 Tahun 2009 Tentang Penyelenggaraan Pencegahan dan Perlindungan Perempuan dan Anak Korban Tindan Kekerasan serta Perda Kabupaten Lombok Timur No.

9 Tahun 2013 Tentang Perlindungan Perdagangan Orang dan Tindak Kekerasan Terhadap Perempuan dan Anak. Namun, meskipun Undangundang penghapusan Kekerasan dalam Rumah Tangga (KDRT) dengan segenap aturan turunannya telah diberlakukan, tidak berarti angka kekerasan terhadap perempuan dan anak menurun, baik secara nasional maupun di tingkat lokal. Ditingkat nasional, jumlah kasus kekerasan terhadap anak dan perempuan meningkat hampir $400 \%$ dalam kurun waktu 2001-2006. ${ }^{2}$ Hal yang sama terjadi di Provinsi Nusa Tenggara Barat, dimana terjadi peningkatan kasus kekerasan terhadap perempuan dan anak (lihat table).

Tabel 1.Jumlah KasusKekerasan Domestik Terhadap Perempuan dan Anak di Lombok Timur

\begin{tabular}{llll} 
NO & $\begin{array}{l}\text { Nama } \\
\text { Kabupaten }\end{array}$ & $\begin{array}{l}\text { Jumlah } \\
\text { Kasus } \\
\mathbf{2 0 1 4}\end{array}$ & $\begin{array}{l}\text { Jumlah } \\
\text { Kasus }\end{array}$ \\
\hline 1 & MATARAM & 148 & 69 \\
2 & LOBAR & 102 & 16 \\
3 & KLU & 7 & 152 \\
4 & LOTENG & 88 & 99 \\
5 & LOTIM & 221 & 178 \\
6 & KSB & 58 & 75 \\
7 & SUMBAWA & 62 & 74 \\
8 & DOMPU & 113 & 245 \\
9 & KOTA BIMA & 38 & 77 \\
10 & KAB.BIMA & 75 & 2 \\
11 & UPT PROVINSI & 217 & 206 \\
& TOTAL & 1,129 & 1,193 \\
\hline
\end{tabular}

Sumber: diolah dari data P3AKB NTB.

Berdasarkan grafik diatas, terlihat jelas angka kekerasan terhadap perempuan dan anak di Pulau Lombok sangat tinggi dan meningkat 5,4\%. Tingginya angka

${ }^{2}$ Kompas, edisi 8 maret 2006. Tahun 2001 3.169 kasus, tahun 20025.163 kasus, Tahun 2003 7.787 kasus, Tahun 200414.020 kasus, dan 2005 meningkat lebih dari $100 \%$ dan mencapai angka 20.391 kasus. Diyakini, angka yang sesungguhnya jauh lebih besar dari ini. 
kekerasan terhadap perempuan dan anak di Pulau Lombok menjadi ironis mengingat label Pulau Seribu Masjid dan masyarakat Islami yang melekat di Pulau ini. Oleh karena itu, kajian akan kekerasan perempuan dan anak di Pulau Lombok menjadi menarik untuk dilakukan.

Secara umum, trend peningkatan kekerasan domestic setidaknya disebabkan oleh 2 faktor penting. Pertama, meningkatnya kesadaran masyarakat, khususnya kaum perempuan, terhadap hak-hak perempuan dan anak dalam memperoleh kehidupan yang nyaman dan jauh dari kekerasan baik fisik, seksual maupun verbal. Kedua, Seiring dengan meningkatnya kesadaran kaum perempmpuan akan hak-haknya, terjadi pula perubahan mindset (paradigma) dalam melihat kekerasan yang menimpa kaum perempuan dan anak. Peristiwa kekerasan domestic tidak lagi dilihat sebagai hal yang tabu dan privat, melainkan telah menjadi wilayah public dan Negara.

Penelitian terhadap kekerasan domestik di Pulau Lombok, terutama di Lombok Timur, menjadi kajian menarik setidaknya karena tiga faktor. Pertama, kekerasan terhadap perempuan dan anak merupakan masalah serius. Hal ini disebabkan mayoritas korban adalah perempuan dan anak yang berada pada masa pertumbuhan. Kekerasan yang menimpa para korban (khususnya kekerasan seksual) dalam jangka panjang sangat potensial mempengaruhi kondisi pertumbuhan kejiwaan para korban, dan bahkan menciptakan generasi balas dendam ${ }^{3}$. Kedua, pelaku kekerasan domestic umumya adalah orang-orang yang memiliki kedekatan dengan korban, baik kedekatan emosional maupun geneologis. Ketiga, kuatnya pengaruh agama, budaya patriarkhi dan struktur social yang saling berkelindan menyebabkan dalam rangkaian kekerasan domestic ini seolah tidak terputus. Pengaruh primordial yang sangat kuat ini menyebabkan mayoritas korban (terutama korban kekerasan seksual dan fisik) menganggap masalah tersebut sebagai area privat, tertutup dan tabu diketahui orang lain. Keempat, Pulau Lombok (khususnya Lombok Timur) dikenal sebagai salah satu sumbu utama penghasil Tenaga Kerja Migran di Indonesia. Keterbatasan akses sumber daya ekonomi dan pendidikan ditengarai sebagai fakor determinan tingginya minat bekerja sebagai migrant worker. Menjadi menarik untuk melacak keterkaitan faktor-faktor diatas dengan tingginya

${ }^{3}$ Seorang anak korban kekerasan seksual, ketika dewasa akan sangat berpotensi menjadi pelaku kekerasan seksual. Demikian pula anakanak korban kekerasan fisik dan verbal akan berpotensi melakukan hal yang sama ketika dewasa. 
angka kekerasan terhadap perempuan dan anak di Lombok Timur.

Secara sosiologis masyarakat Sasak di Pulau Lombok menganut system patrilineal, dimana laki-laki memegang peranan dominan dalam keluarga, struktur social dan budaya. System patrilineal menempatkan lakilaki sebagai pusat dariseluruh aktivitas social, budaya dan ekonomi, dan menempatkan perempuan pada posisi marginal ${ }^{4}$. Sistem social ini berkaitan erat dengan keyakinan religious masyarakat Sasak yang di dominasi Islam tradisional. Singkatnya, system social dan pengetahuan keagamaan yang terbatas, membentuk alur fikir masyarakat Sasak yang menempatkan perempuan dalam posisi "di belakang". ${ }^{5}$

Di sisi lain, perkembangan ekonomi kapitalistik yang berbasis pada individualism menyebabkan perubahan social secara fundamental. Penetrasi teknologi hingga ke sudutsudut kota dan desa mengubah watak dan karakter masyarakatnya. Hal ini berimplikasi pada perubahan struktur dasar sebuah keluarga, dimana keluarga besar (extended family)

${ }^{4}$ Contoh kecil dominasi laki-laki dalam system patrilineal Sasak terlihat dari "pembiaran" bangsawan laki-laki menikah dengan perempuan non-bangsawan, dan sebaliknya "hukuman" bagi perempuan bangsawan yang menikah dengan laki-laki non-bangsawan atau tidak sederajat.

${ }^{5}$ Dalam terminology Jawa, situasi perempuan seperti ini dikenal dengan "konco wingking" atau "teman tidur". cenderung mengalami penyempitan danberpusatpadakeluargainti (nucleus family). Pelibatan dan tanggungjawab keluarga besar dalam pendidikan dan pembentukan karakter anggota keluarga besar semakin berkurang, dan keluarga inti cenderung menjadi eksklusif ${ }^{6}$. Masyarakat Sasak yang dahulu dikenal homogen dan religius) relative telah berubah menjadi masyarakat yang cendrung individualis. Ketimpangan akses atas basis-basis ekonomi dan pendidikan, menyebabkan masyarakat di pedesaan semakin termarjinalkan dan mengalami mengalami keterkejutan budaya (shock culture).

Berdasarkan paparan diatas, maka penelitian ini akan fokus mengkaji kekerasan terhadap perempuan dan anak di Lombok Timur. Guna mempertajam analisis, maka rumusan pertanyaannya adalah: Bagaimana bentuk-bentuk kekerasan terhadap perempuan dan anak dalam keluarga di Lombok Timur?, Faktor-faktor apa yang menyebabkan terjadinya kekerasan terhadap perempuan dan anak dalam keluarga di Lombok Timur ? dan bagaimana relasi antara pelaku dengan korban kekerasan perempuan dan anak?

${ }^{6}$ T.O. Ihromi, Bunga Rampai Sosiologi Keluarga (Jakarta: Yayasan Obor Indonesia, 2004), h. 90 


\section{B. Metode Penelitian}

1. Pendekatan dan jenis penelitian

Seperti dikemukakan di atas bahwa penelitian ini berupaya untuk melihat fenomena kekerasan domestik perempuan dan anak di LombokTimur.Untukitu, diperlukan sebuah pendekatan yang mampu memberikan alat untuk menggali, mencermati dan menganalisa kasus yang diteliti. Atas dasar itu, metode dalam penelitian ini menggunakan penelitian kualitatif atau deskriftif analitis $^{7}$ dengan menggunakan pendekatan normatif empiris, dalam hal ini menggunakan pendekatan yang mengacu pada Undangundang No. 23 tahun 2004 Tentang Penghapusan Kekerasan dalam rumah tangga dan Undang-undang lain yang menjadi perlindungan hukum terhadap perempuan dan anak korban kekerasan domestik. Dengan pendekatan ini diharapkan mampu memberikan instrumentasi untuk mempelajari, menerangkan pelaksanaan konsep diversi pada pemeriksaan di persidangan.

2. Teknik pengumpulan data

Untuk mendapatkan data yang komprehensif, penelitian ini akan menggunakan teknik pencarian

${ }^{7}$ Penelitian Deskriptif Analitik yaitu penelitian untuk menyelesaikan masalah dengan cara mendeskripsikan masalah melalui pengumpulan, penyusunan, analisa data, penjelasan kemudian diberikan penilaian (lihat Rianto adi, Metode Penelitian Sosial dan Hukum, (Granit: Jakarta, 200) h. 124). data, yaitu pertama, studi pustaka; kedua,observasi, ketiga wawancara dan keempat dokumentasi. Langkah pertama yang akan dilakukan adalah studi literatur untuk menggali data sekunder berupa buku, hasil-hasil penelitian yang relevan dengan tema yang diangkat, terutama undangundang yang berkaitan dengan perlindungan anak dan peradilan pidana anak. Hal ini dilakukan untuk menambah pemahaman teoritik dan konseptual tentang obyek yang diteliti. Disamping literatur, pembacaan obyek penelitian juga akan dilakukan melalui studi media. Dengan studi media ini diharapkan peneliti akan memperoleh informasi lebih mengenai obyek yang diteliti, khususnya mengenai peristiwaperistiwa yang pernah terjadi.

Langkah kedua yang akan dilakukan peneliti adalah observasi, ketiga yaitu wawancara. Dalam penelitian ini peneliti akan menggunakan wawancara terstruktur dan tidak terstruktur. Wawancara diharapkan mampu memberikan keterangan-keterangan dan buktibukti empirik serta informasi akurat terhadap obyek penelitian, sehingga peneliti mampu mengidentifikasi sumber-sumber bukti yang relevan. Data dan informasi yang diperoleh peneliti dalam wawancara ini sekaligus menjadi data primer dalam penelitian ini. 
Data wawancara dari satu informan akan di cross check analysis dengan informan lain, sehingga akan diketahui ada tidaknya perbedaan pendapat atau informasi dari masingmasing sumber. Jika terjadi perbedaan akan diketahui alasan-alasannya tanap mengurangi obyektivitas penelitian. Wawancara akan dilakukan pada pihak-pihak yang terkait dengan kekerasan domestik terhadap perempuan dan anak, seperti yang sudah disebutkan dalam sumber data primer. Setelah wawancara dilakukan, maka langkah keempat yaitu dengan melakukan dokumentasi terhadap data-data korban, pelaku kekerasan terhadap perempuan dan anak serta atauran yang mengaturnya di Kabupaten Lombok Timur.

3. Analisis data

Selanjutnya peneliti akan menganalisa data yang didapat. Data empirik akan dianalisis kembali secara cross check analysis dengan sumber-sumber literatur, sehingga pemahaman dan kedalaman analisa bisa diperoleh. Analisis data akan dilakukan secara deduktif, dengan dimulai hal-hal yang bersifat umum terkait penelitian, kemudian akan ditarik kesimpulan seccara lebih khusus terkait dengan kekerasan domestik terhadap perempuan dan anak yang terjadi di Lombok Timur.

\section{Hasil Penelitian}

\section{Kekerasan}

a. Pengertian Kekerasan

Awal mulanya istilah tindak kekerasan pada anak atau child abuse dan neglect dikenal dari dunia kedokteran. Sekitar tahun 1946, Caffey-seorang radiologist melaporkan kasus cedera yang berupa gejala-gejala klinik seperti patah tulang panjang yang majemuk (multiple fractures) pada anakanak atau bayi disertai pendarahan subdural tanpa mengetahui sebabnya (unrecognized trauma). Dalam dunia kedokteran, istilah ini dikenal dengan istilah Caffey Syndrome. Sedang Burker mendifinisikan child abuse merupakan tindakan melukai beulang-ulang secara fisik dan emosional terhadap anak yang ketergantungan, melalui desakan hasrat, hukuman badan yang tak terkendali, degradasi dan cemoohan permanen atau kekerasan seksual. Kekerasan seksual merupakan bentuk kontak seksual atau bentuk lain yang tidak diinginkan secara seksual. Kekerasan seksual biasanya disertai dengan tekanan psikologis atau fisik. Perkosaan merupakan jenis kekerasan seksual yang spesifik. Perkosaan dapat didefiniskan sebagai penetrasi seksual tanpa izin atau dengan paksaan, disertai oleh kekerasan fisik. 
b. Bentuk-bentuk Kekerasan terhadap Anak

Menurut Terry E. Lawson, psikiater internasional yang merumuskan definisi tentang child abuse, menyebut ada empat macam abuse, yaitu: ${ }^{8}$

1. Kekerasan secara Fisik (physical abuse).

2. Kekerasan Emosional (emotional abuse).

3. Kekerasan secara Verbal (verbal abuse)

4. Kekerasan Seksual (sexual abuse) Sexual abuse meliputi pemaksaan hubungan seksual yang dilakukan terhadap orang yang menetap dalam lingkup rumah tangga tersebut (seperti istri, anak dan pekerja rumah tangga). Selanjutnya dijelaskan bahwa sexual abuse adalah setiap perbuatan yang berupa pemaksaan hubungan seksual, pemaksaan hubungan seksual dengan cara tidak wajar dan atau tidak disukai, pemaksaan hubungan seksual dengan orang lain untuk tujuan komersil dan atau tujuan tertentu. Kekerasan seksual (sexual abuse) merupakan jenis penganiayaan yang biasanya dibagi

Sedangkan kategori berdasarkan identitas pelaku terdiri dari:

${ }^{8} \mathrm{Abu}$ Huraerah, Kekerasan Terhadap Anak, Cet. Ke 3, Nuansa Cendekia, 2012, h.33 a) Familial Abuse

Incest merupakan sexual abuse yang masih dalam hubungan darah, menjadi bagian dalam keluarga inti. Seseorang yang menjadi pengganti orang tua, misalnya ayah tiri, atau kekasih, termasuk dalam pengertian incest. Kategori incest dalam keluarga dan mengaitkan dengan kekerasan pada anak.

Kategori pertama, sexual molestation (penganiayaan). Hal ini meliputi interaksi noncoitus, petting, fondling, exhibitionism, dan voyeurism, semua hal yang berkaitan untuk menstimulasi pelaku secara seksual.

Kategori kedua, sexual assault (perkosaan), berupa oral atau hubungan dengan alat kelamin, masturbasi, fellatio (stimulasi oral pada penis), dan cunnilingus (stimulasi oral pada klitoris). Kategori terakhir yang paling fatal disebut forcible rape (perkosaan secara paksa), meliputi kontak seksual. Rasa takut, kekerasan, dan ancaman menjadi sulit bagi korban. Mayer mengatakan bahwa paling banyak ada dua kategori terakhir yang menimbulkan trauma terberat bagi anak-anak, namun korban-korban sebelumnya tidak mengatakan demikian. Mayer berpendapat derajat trauma tergantung pada tipe 
dari kekerasan seksual, korban dan survivor mengalami hal yang sangat berbeda. Survivor yang mengalami perkosaan mungkin mengalami hal yang berbeda dibanding korban yang diperkosa secara paksa.

b) Extrafamilial Abuse

Extrafamilial Abuse, dilakukan oleh orang lain di luar keluarga korban, dan hanya $40 \%$ yang melaporkan peristiwa kekerasan. Kekerasan seksual yang dilakukan oleh orang dewasa disebut pedophile, yang menjadi korban utamanya adalah anak-anak. Pedophilia diartikan"menyukaianak-anak". Pedetrasy merupakan hubungan seksual antara pria dewasa dengan anak laki-lakiPornografi anak menggunakan anakanak sebagai sarana untuk menghasilkan gambar, foto, slide, majalah, dan Biasanya ada tahapan yang terlihat dalam melakukan kekerasan seksual kemungkinan pelaku mencoba perilaku untuk mengukur kenyamanan korban. Jika korban menuruti, kekerasan akan berlanjut dan intensif, berupa: Nudity (dilakukan oleh orang dewasa),Disrobing (orang dewasa membuka pakaian di depan anak),Genital exposure (dilakukan oleh orang dewasa), Observation of the child (saat mandi, telanjang, dan saat membuang air) dan mencium anak yang memakai pakaian dalam. Fondling (meraba-raba dada korban, alat genital, paha, dan bokong). Masturbasi, Fellatio (stimulasi pada penis, korban atau pelaku sendiri). Cunnilingus (stimulasi pada vulva atau area vagina, pada korban atau pelaku). Digital penetration (pada anus atau rectum) terdiri dari : Penile penetration (pada vagina), Digital penetration (padavagina). Penilepenetration (pada anus atau rectum). Dry intercourse (mengelus-elus penis pelaku atau area genital lainnya, paha, atau bokong korban) (Sgroi dalam Tower, 2002).

Menurut Bagong dalam bukunya " Tindak kekerasan Terhadap Anak: Masalah dan Upaya Pemantauannya", mengelompokkan kekerasan pada anak menjadi: ${ }^{9}$

1) Kekerasan Anak Secara Fisik. Kekerasan secara fisik adalah penyiksaan, pemukulan, dan penganiayaan terhadap anak, dengan atau tanpa menggunakan benda-benda tertentu, yang menimbulkan luka-luka fisik atau kematian pada anak. Bentuk luka dapat

${ }^{9}$ Bagong Suyanto, Tindak kekerasan Terhadap Anak: Masalah dan Upaya Pemantauannya( Surabaya: Kerjasama LPA Jatim dan UNICEF, 2000), h.5 
berupalecetataumemarakibat persentuhan atau kekerasan benda tumpul, seperti bekas gigitan, cubitan, ikan pinggang, atau rotan.Dapat pula berupa luka bakar akibat bensin panas atau berpola akibat sundutan rokok atau setrika. Lokasi luka biasanya ditemukan pada daerah paha, lengan, mulut, pipi, dada, perut, punggung atau daerah bokong. Terjadinya kekerasan terhadap anak secara fisik umumnya dipicu oleh tingkah laku anak yang tidak disukai orangtuanya, seperti anak nakal atau rewel, menangis terus, minta jajan, buang air atau muntah di sembarang tempat, memecahkn barang berharga.

2) Kekerasan Anak Secara Psikis.

kekerasan secara psikis meliputi penghardikan, penyampaian kata-kata kasar dan kotor, memperlihatkan buku, gambar, dan film pornografi pada anak. Anak yang mendapatkan perlakuan ini umumnya menunjukkan gejala perilaku maladaptif, seperti menarik diri, pemalu, menangis jika didekati, takut ke luar rumah dan takut bertemu dengan orang lain.
3) Kekerasan Anak Secara Seksual

Kekerasan secara seksual dapat berupa perlakuan prakontak seksual antara anak dengan orang yang lebih besar (melalui kata, sentuhan, gambar visual, exhibisionism), maupun perlakuan kontak seksual secara langsung antara anak dengan orang dewasa (incest, perkosaan, eksploitasi seksual).

4) Kekerasan Anak Secara Sosial.

Kekerasan secara sosial dapat mencakup penelantaran anak dan eksploitasi anak. Penelantaran anak adalah sikap dan perlakuan orangtua yang tidak memberikan perhatian yang layak terhadap prosestumbuh-kembanganak. Misalnya anak dikucilkan, diasingkan dari keluarga, atau tidak diberikan pendidikan dan perawatan kesehatan yang layak.

Eksploitasi anak menunjuk pada sikap diskriminatif atau perlakuan sewenang-wenang terhadap anak yang dilakukan keluarga atau masyarakat. Sebagai contoh, memaksa anak untuk melakukan sesuatu demi kepentingan ekonomi, sosial, atau politik tanpa memperhatikan hak- 
hak anak untuk mendapatkan perlindungan sesuai dengan perkembangan fisik, psikisnya dan status sosialnya. Misalnya, anak dipaksa untuk bekerja di pabrikpabrik yang membahayakan (pertambangan, sektor alas kaki) dengan upah rendah dan tanpa peralatan yang memadai, anak dipaksa untuk angkat senjata, atau dipaksa melakukan pekerjaan-pekerjaan rumah tangga melebihi batas kemampuannya.

c. Faktor-fakor Penyebab Kekerasan terhadap Anak

Gelles Richard.J, mengemukakan bahwa kekerasan terhadap anak (child abuse) terjadi akibat kombinasi dari berbagai faktor, yaitu:

1) Pewarisan Kekerasan Antar Generasi (intergenerational transmission of violance).

Banyak anak belajar perilaku kekerasan dari orangtuanya dan ketika tumbuh menjadi dewasa mereka melakuakan tindakan kekerasan kepada anaknya. Dengan demikian, perilaku kekerasan diwarisi (transmitted) dari generasi ke generasi. Studi-studi menunjukkan bahwa lebih kurang 30\% anak-anak yang diperlakukan dengan kekerasan menjadiorangtuayangbertindakkeras kepada anak-anaknya. Sementara itu, hanya 2 sampai 3 persen dari semua individu menjadi orangtua yang memperlakukan kekerasan kepada anak-anaknya. Anak-anak yang mengalami perlakuan salah dan kekerasan mungkin menerima perilaku ini sebagai model perilaku mereka sendiri sebagai orangtua.

Tetapi, sebagian besar anak-anak yang diperlakukan dengan kekerasan tidak menjadi orang dewasa yang memperlakukan kekerasan kepada anak-anaknya.

2) Stres Sosial (social stress)

Stres yang ditimbulkan oleh berbagai kondisi sosial meningkatkan risiko kekerasan terhadap anak dalam keluarga. Kondisi-kondisi sosial ini mencakup: pengangguran (unemployment), penyakit (illness), kondisiperumahanburuk(poorhousing conditions), ukuran keluarga besar dari rata-rata (a larger than average family size), kelahiran bayibaru (the presence of a new baby), orang cacat (disabled person) di rumah, dan kematian (the death) seorang anggota keluarga. Sebagian besar kasus dilaporkan tentang tindakan kekerasan terhadap anak berasal dari keluarga yang hidup dalam kemiskinan. Tindakan kekerasan terhadap anak juga terjadi dalam keluarga kelas menengah dan kaya, tetapi tindakan yang dilaporkan lebih banyak di antara keluarga miskin karena beberapa alasan.

3) Isolasi Sosial dan Keterlibatan Masyarakat Bawah 
Orangtua dan pengganti orangtua yang melakukan tindakan kekerasan terhadap anak cenderung terisolasi secara sosial. Sedikit sekali orangtua yang bertindak keras ikut serta dalam suatu organisasi masyarakat dan kebanyakan mempunyai hubungan yang sedikit dengan teman atau kerabat.

3) Kekerasan Domestik

Kekerasan domestik terdiri dari Pelecehan Dalam Rumah Tangga (Domestic Abuse) yang terjadi jika seseorang di dalam keluarga atau pernikahan mencoba untuk menguasai atau/dan mengkontrol anggota keluarga yanglain.Sedangkan Kekerasan Dalam Rumah Tangga (Domestic Violence) adalah Pelecehan di dalam rumah tangga yang mengikutsertakan kekerasan fisik.

Anne Grant menjelaskan bahwa kekerasan domestik adalah kekerasan yang terjadi di dalam rumah tangga dimanabiasanyayangberjeniskelamin laki - laki (suami) menganiaya secara verbal ataupun fisik pada yang berjenis kelamin perempuan (istri). Sehinnga Anne Grant mendefisinsikan KDRT sebagai pola perilaku menyimpang (assaultive) dan memaksa (corsive), termasuk serangan secara fisik, seksual, psikologis, dan pemaksaan secara ekonomi yang dilakukan oleh orang dewasa kepada pasangan intimnya. ${ }^{10}$

Kekerasan dalam rumah tangga, sebagaimana disebutkan dalam Undang-undang No. 23 Tahun 2004 tentang Penghapusan kekerasan Dalam Rumah Tangga (UU PKDRT), adalah setiap perbuatan terhadap seseorang terutama perempuan, yang berakibat timbulnya kesengsaraan atau penderitaan secara fisik, seksual, psikologis, dan/atau penelantaran rumah tangga termasuk ancaman untuk melakukan perbuatan, pemaksaan, atau perampasan kemerdekaan secara melawan hukum dalam lingkup rumah tangga.

Dalam Undang- undang No 23 tahun 2004, pada pasal 1. ayat (1) disebutkan bahwa kekerasan dalam rumah tangga adalah setiap perbuatan terhadap seseorang terutama perempuan yang berakibat timbulnya kesengsaraan atau penderitaan secara fisik, seksual, psikologis dan atau pemelantaran rumah tangga termasuk ancaman untuk melakukan perbuatan, pemaksaan, atau perampasan kemerdekaan secara melawan hukum dalam lingkup rumah tangga.

${ }^{10}$ Anne Grant, Domestic Violence, Abuse, and Child Custody: Legal Strategies and Policy Issues, ed. Mo Therese Hannah, PhD, and Barry Goldstein ( JD Civic Research Institute, 2010), h. 9 
4) Kekerasan, Perempuan dan Ketidaksetaraan Gender

Kekerasanberartipenganiayaan, penyiksaan, atau perlakuan salah. Menurut WHO kekerasan adalah penggunaan kekuatan fisik dan kekuasaan, ancaman atau tindakan terhadap diri sendiri, perorangan atau sekelompok orang atau masyarakat yang mengakibatkan atau kemungkinan besar mengakibatkan memar/trauma, kematian, kerugian psikologis, kelainan perkembangan atau perampasan hak. Awal mulanya istilah tindak kekerasan pada anak atau child abuse dan neglect dikenal dari dunia kedokteran. Sekitar tahun 1946, Caffey-seorang radiologist melaporkan kasus cedera yang berupa gejala-gejala klinik seperti patah tulang panjang yang majemuk (multiple fractures) pada anakanak atau bayi disertai pendarahan subdural tanpa mengetahui sebabnya (unrecognized trauma). Dalam dunia kedokteranistilah ini dikenal dengan istilah Caffey Syndrome. ${ }^{11}$

Pengertian kekerasan dalam undang-undang pada awalnya dapat dilihat dalam pasal 89 KUHP yang berbunyi: "membuat orang pingsan atau tidak berdaya disamakan dengan menggunakan kekerasan". Pada pasal tersebut tidak menjelaskan bagaimana bentuk-bentuk kekerasan tersebut, sedangkan pengertian tidak berdaya

${ }^{11}$ Jurnal LBH APIK Tentang Kekerasan Perempuan dan Anak, 2003, h. 10. adalah tidak memiliki kekuatan atau tenaga sama sekali, sehingga tidak dapat mengadakan perlawanan sedikitpun. Akan tetapi, pada pasal dalam KUHP seringkali kekerasan dikaitkan dengan ancaman. Dengan demikian dapat disimpulkan bahwa kekerasan dapat berbentuk fisik dan nonfisik. (ancaman kekerasan). ${ }^{12}$

Dalam literatur terdapat beberapa penggunaan pengertian kekerasan tehadap orang lain, yaitu violence, battery dan assault. Violence (Kekerasan) dapat diartikan sebagai unjust or unwarranted exercise of force with the accompaniment of vehemence, outrage or fury, fhysical force. Pengertian Baterry itu: criminal battery, defined as the unlawful aplication of force to the person. Sedangkan assault adalah anny willful attempt or threat to inflict injury upon the person of another.

Berdasarkan pengertian di atas, terminologi kekerasan terhadap perempuan memiliki ciri bahwa tindakan tersebut:

a) Dapat berupa fisik dan nonfisik (psikis).

b) Dapat dilakukan secara aktif maupun dengan cara pasif (tidak Berbuat).

c) Dikehendaki/ diminati oleh para pelaku.

${ }^{12}$ Moerti Hadiati Soeroso, Kekerasan Dalam Rumah Tangga, Perspektif Viktimologis dan Kriminologis ( Surabaya; Sinar Grafika, 2004), h. 58. 
d) Adanya akibat/kemungkinan akibat yang merugikan pada korban (fisik atau psikis) yang tidak dikehendaki korban. ${ }^{13}$

Masalah tindak kekerasan terhadap perempuan tidak terlepas dari dominasi dari seseorang terhadaporang lain. Seks (jenis kelamin) harus dibedakan dengan gender. Pengertian jenis kelamin merupakan pensifatan atau pembagian dua jenis kelamin manusia yang ditentukan secara biologis yang melekatpadakelamintertentu.Karena sifatnya sifatnya melekat dengan sendirinya tidak dapat dipertukarkan. Secara permanen tidak berubah dan merupakan ketentuan biologis atau sering dikatakan sebagai ketentuan Tuhan atau Kodrat, jadi kodrat perempuan adalah menstruasi/haid, hamil, melahirkan dan menyusui. Adapun laki-laki memiliki penis, jakun dan memproduksi sperma.

Hal ini sangat perlu mendapatkan perhatian semua pihak agar mendapatkan kejelasan, karena masih terdapat pandangan dalam masyarakat bahwa peran domesti, seperti memasak, mengurus rumah, mendidik anak adalah kodrat perempuan.

Sedangkan gender adalah cara pandang atau persepsi manusia terhadap perempuan atau lakilaki yang bukan didasarkan pada

13 Ibid, h. 60. perbedaan jenis kelamin secara kodrati biologis. Gender dalam segala aspek kehidupan manusia mengkreasikan perbedaan antara perempuan dan laki-laki termasuk kreasi social kedudukan perempuan yang lebih rendah daripada laki-laki.

Pandangan gender ternyata dapat menimbulkan subordinasi terhadap perempuan. Anggapan bahwa perempuan itu irrasional atau emosional, sehingga perempuan tidak bias tampil memimpin berakibat munculnya sikap yang menempatkan perempuan pada posisi yang tidak penting. Subordinasi karena gender tersebut terjadi dalam bentuk yang berbeda dari tempat ke tempat dan dari waktu ke waktu. ${ }^{14}$

Di Indonesia persoalan ketimpangan hubungan kekuasaan (relasi social) telah berlangsung lama, seperti kedudukan subordinasi perempuan yang antara lain disebabkan karena relasi gender yang tidak seimbang anatara suami istri dalam keluarga, interpretasi ajaran agama yang membenarkan suami memukul istri, pemberian hak kepada suami untuk memiliki kekuasaan yang lebih tinggi karena ia adalah pemimpin dan pemberi nafkah. Nilainilai tersebut tampak dikukuhkan dalam Undang-undang No. 1 Tahun 1974 tentang perkawinan, pasal 34

${ }^{14}$ Mansour Fakih, Analisis Gender dan Transformasi Sosial (Yogyakarta:tt, 1999), h. 15. 
ayat 1 dan 2 ysng mengstur pembagian peran laki-laki dan perempuan dalam rumah tangga secara bias gender dan sekaligus menempatkan posisi perempuan sebagai subordinasi dari laki-laki, baik secara ekonomi, social dan politik.

d. Bentuk-bentuk kekerasan terhadap perempuan dan anak dalam keluarga di Lombok Timur.

Rumah tangga merupakan bentuk masyarakat yang paling kecil, yang biasanya terdiri dari ayah, ibu dan anak. Sebuah rumah tangga diharapka memancarkankebahagiaan dan kehangatan penuh cinta dan kasih. Namun seringkali terjadi kegoncangan dalam rumah tangga tersebut berupa tindakan kekerasan yang dilakukan oleh suami pada istri, anak maupun anggota keluarga yang lain. Perbuatan tersebut oleh masyarakat dan bahkan oleh korban dianggap merupakan masalah intern keluarga.

Kasus penelantaran,penyiksaan, bahkan pembunuhan yang dilakukan oleh orangtua terhadap anak sering terjadi di indonesia, meski terus disoroti oleh masyarakat dan pemerintah, kasuskekerasan terhadap anak seakan tidak bisa diredam.

Begitu halnya dengan di Lombok Timur, kasus-kasus kekerasan terhadap perempuan dan anak terus berulang dan cukup

banyak. Walaupun menurut data dari BP3AKB propinsi NTB data kekerasan terhadap perempuan dan anak di Lombok Timur tahun 2016 berkurang dari tahun sebelumnya, yaitu dengan 77 kasus, namun ini sebenarny belum menjamin bahwa kekerasan-kekerasan terhadap perempuan dan anak pada praktiknya semakin berkurang.

Table. 2 Bentuk-bentuk Kekerasan Domestik Perempuan dan Anak di Lombok Timur

\begin{tabular}{|c|c|c|c|}
\hline \multirow{2}{*}{ NO } & \multirow{2}{*}{ BENTUK KEKERASAN } & \multicolumn{2}{|c|}{ JUMLAH KASUS } \\
\hline & & 2014 & 2015 \\
\hline 1 & Kekerasan Fisik & 140 & 92 \\
\hline 2 & Kekerasan Psikis & 40 & 40 \\
\hline 3 & Kekerasan Seksual & 36 & 59 \\
\hline 4 & Kekerasan Penelantaran & 14 & 18 \\
\hline 5 & Kekerasan Eksploitasi & 2 & 14 \\
\hline 6 & Kekerasan Trafficking & - & 3 \\
\hline 7 & Kekerasan Lainnya & - & 7 \\
\hline
\end{tabular}
NTB 
Table 3. Usia Korban Kekerasan Domestik Perempuan dan Anak di Lombok Timur.

\begin{tabular}{|c|c|c|c|c|c|c|c|}
\hline \multicolumn{4}{|c|}{ TAHUN 2015} & \multicolumn{4}{|c|}{ TAHUN 2014} \\
\hline \multicolumn{4}{|c|}{ USIA/JUMLAH } & \multicolumn{4}{|c|}{ USIA/JUMLAH } \\
\hline $60 \mathrm{Thn}$ & 25-29 Thn & 18-24 Thn & 0-17 Thn & 60 Thn & 25-29 Thn & 18-24 Thn & 0-17 Thn \\
\hline 1 Org & 26 Org & 15 Org & 46 Org & 2 Org & 74 Org & 44 Org & 64 Org \\
\hline
\end{tabular}

Dari table di atas terlihat bahwa usia korban dari tahun ke tahun, yaitu 2014-2015 yang paling tinggi adalah jumlah kasus kekerasan yang dialami oleh anak perempuan usia 0-17 tahun, yaitu 2014, 64 orang korban atau kasus, 201546 korban.Usia 18 -24 tahun 44 kasus tahun 2014, 201515 kasus dan usia 26-29 tahun pada tahun 2014 74 orang/kasus dan 201526 orang/ kasus. Sedangkan perempuan dewasa bahkan tergolong sudah usia lanjut yaitu berusia 60 tahun hanya terjadi 2 kasus saja pada 2014 dan 2015 hanya 1 kasus.

Tabel 4. Tingkat pendidikan Korban kekerasan perempuan dan anak di Lombok Timur

\begin{tabular}{|c|c|c|c|c|c|c|c|c|c|}
\hline \multicolumn{4}{|c|}{ TAHUN 2014 } & \multicolumn{5}{c|}{ TAHUN 2015 } \\
\hline PENDIDIKAN/JUMLAH & \multicolumn{5}{c|}{ PENDIDIKAN/JUMLAH } \\
\hline Tdk Sekolah & SD & SLTP & SLTA & PT & $\begin{array}{c}\text { Tdk } \\
\text { Sekolah }\end{array}$ & SD & SLTP & SLTA & PT \\
\hline 41 & 49 & 48 & 35 & 11 & 36 & 1 & 15 & 28 & 28 \\
\hline
\end{tabular}

Table 5. Tingkat PekerjaanKorban Kekerasan Perempuan dan Anak di LombokTimur

\begin{tabular}{|c|c|c|c|}
\hline \multicolumn{2}{|c|}{ TAHUN 2014 } & \multicolumn{2}{c|}{ TAHUN 2015 } \\
\hline \multirow{2}{*}{ BEKERJA } & $\begin{array}{c}\text { TIDAK } \\
\text { BEKERJA }\end{array}$ & BEKERJA & $\begin{array}{c}\text { TIDAK } \\
\text { BEKERJA }\end{array}$ \\
\hline 52 & 132 & 71 & 5 \\
\hline
\end{tabular}


Tabel 6. Status Perkawinan Korban Kekerasan Perempuan dan Anak di Lombok Timur

\begin{tabular}{|c|c|c|c|c|c|}
\hline \multicolumn{3}{|c|}{ TAHUN 2014} & \multicolumn{3}{c|}{ TAHUN 2015 } \\
\hline \multirow{2}{*}{ MENIKAH } & $\begin{array}{c}\text { TIDAK } \\
\text { MENIKAH }\end{array}$ & CERAI & MENIKAH & $\begin{array}{c}\text { TIDAK } \\
\text { MENIKAH }\end{array}$ & CERAI \\
\hline 100 & 79 & 5 & 36 & 50 & 2 \\
\hline
\end{tabular}

Dari table 4 di atas dapat diketahui bahwa pendidikan korban rata-rata masih pada tahap sekolah, baik SD, SMP maupun SMA bahkan tidak berpendidikan yang mencapai 41 pada tahun 2014 dan 36 pada tahun 2015 mencapai 36 kasus/orang. Sedangkan pada table 5 memperlihatkan bahwa tahun 2014 korban yang tidak bekerja banyak menjadi korban, mencapai 132 orang/kasus dan tahun 2015 yang tidak bekerja hanya 5 orang, yang bekerja 71 orang/kasus. Pada table 6 menunjukkan status korban, yaitu 100 orang/kasus korban dalam status perkawinan pada 2014, tidak menikah 79 kasus. Sedangkan 201550 0rang menikah dan 36 tidak dalam status perkawinan atau tidak menikah

e. Faktor-faktor apa yang menyebabkan terjadinya kekerasan terhadap perempuan dan anak dalam keluarga.

Berbagai faktor yang menyebabkan atau menjadi pemicu kekerasan domestik terhadap perempuan dan anak di Lombok Timur, yaitu:

1. Masalah keuangan atau ekonomi;

2. Masalah anak;

3. Masalah cemburu;

4. Masalah saudara;

5. Masalah sopan santun;

6. Masalah masa lalu;

7. Salah paham;

8. Mau menang sendiri;

9. Tidak dapat menahan nafsu dan emosi 
Table 7. Ciri-ciri pelaku kekerasan perempuan dan anak berdasarkan tingkat usia di lombok timur

\begin{tabular}{|c|c|c|c|c|c|c|c|}
\hline \multicolumn{4}{|c|}{ TAHUN 2014} & \multicolumn{4}{|c|}{ TAHUN 2015} \\
\hline \multicolumn{4}{|c|}{ USIA/JUMLAH } & \multicolumn{4}{|c|}{ USIA/JUMLAH } \\
\hline 0-17 Thn & 18-24Thn & 25-29Thn & 60 Thn & 0-17 Thn & 18-24 Thn & 25-29 Thn & 60 Thn \\
\hline 29 org & 42 org & 145 Org & $120 \mathrm{rg}$ & 13 Org & 22 org & $710 \mathrm{rg}$ & $10 \mathrm{rg}$ \\
\hline
\end{tabular}

Table. 8 Ciri-ciri Pelaku Kekerasan Perempuan dan anak Berdasarkan Tingkat Pendidikan di lombok Timur

\begin{tabular}{|l|l|l|l|l|l|l|l|l|l|}
\hline \multicolumn{3}{|c|}{ TAHUN 2014} & \multicolumn{5}{c|}{ TAHUN 2015 } \\
\hline \multicolumn{3}{|c|}{ PENDIDIKAN/JUMLAH } & \multicolumn{5}{c|}{ PENDIDIKAN/JUMLAH } \\
\hline Tdk Sekolah & SD & SLTP & SLTA & PT & $\begin{array}{l}\text { Tdk } \\
\text { Sekolah }\end{array}$ & SD & SLTP & SLTA & PT \\
\hline 82 & 51 & 34 & 44 & 17 & 62 & 4 & 8 & 9 & 15 \\
\hline
\end{tabular}

Table. 9 Ciri-ciri Pelaku Kekerasan Perempuan dan anak Berdasarkan Pekerjaan di lombok timur

\begin{tabular}{|c|c|c|c|}
\hline \multicolumn{2}{|c|}{ TAHUN 2014 } & \multicolumn{2}{c|}{ TAHUN 2015 } \\
\hline \multirow{2}{*}{ BEKERJA } & TIDAK BEKERJA & BEKERJA & TIDAK BEKERJA \\
\hline 116 & 112 & 57 & 38 \\
\hline
\end{tabular}


Tabel. 10 Relasi/Hubungan Antara Pelaku Dan Korban

\begin{tabular}{|c|c|c|c|c|c|c|c|}
\hline \multicolumn{4}{|c|}{ TAHUN 2014} & \multicolumn{4}{|c|}{ TAHUN 2015} \\
\hline $\begin{array}{c}\text { Orang } \\
\text { Tua }\end{array}$ & Keluarga & $\begin{array}{c}\text { Suami/ } \\
\text { Istri }\end{array}$ & Lainnya & $\begin{array}{c}\text { Orang } \\
\text { Tua }\end{array}$ & Keluarga & $\begin{array}{c}\text { Suami/ } \\
\text { Istri }\end{array}$ & Lainnya \\
\hline $260 \mathrm{rg}$ & 12 org & 84 Org & $1160 \mathrm{rg}$ & 17 Org & 4 Org & $390 \mathrm{rg}$ & 47 Org \\
\hline
\end{tabular}

\section{Pembahasan}

\section{Bentuk-bentuk kekerasan terhadap perempuan dan anak dalam keluarga di Lombok Timur.}

Bentuk-bentuk kekerasan perempuan dan anak di Lombok Timur yaitu: Kekerasan Fisik, Kekerasan Psikis, Kekerasan Seksual, Kekerasan Penelantaran, Kekerasan Eksploitasi, Kekerasan Trafficking.

Menurut Terry E. Lawson, psikiater internasional yang merumuskan definisi tentang child abuse, menyebut ada empat macam abuse, yaitu: ${ }^{15}$

1) Kekerasan secara Fisik (physical abuse).

Physical abuse, terjadi ketika orang tua/pengasuh dan pelindung anak memukul anak. Pukulan akan diingat anak itu jika kekerasan fisik itu berlangsung dalam periode tertentu. Kekerasan yang

${ }^{15} \mathrm{Abu}$ Huraerah, Kekerasan Terhadap Anak, Cet. Ke 3, Nuansa Cendekia, 2012, h.33 dilakukan seseorang berupa melukai bagian tubuh anak.

2) Kekerasan Emosional (emotional abuse).

Emotional abuse terjadi ketika orang tua/pengasuh dan pelindung anak setelah mengetahui anaknya meminta perhatian, mengabaikan anak itu. Ia membiarkan anak basah atau lapar karena ibu terlalu sibuk atau tidak ingin diganggu pada waktu itu. Ia boleh jadi mengabaikan kebutuhan anak untuk dipeluk atau dilindungi. Kekerasan secara Verbal (verbal abuse)

3) Kekerasan Seksual (sexual abuse)

Sexual abuse meliputi pemaksaan hubungan seksual yang dilakukan terhadap orang yang menetap dalam lingkup rumah tangga tersebut (seperti istri, anak dan pekerja rumah tangga).

Sedangkan kategori berdasarkan identitas pelaku terdiri dari: 
1) Familial Abuse

Incest merupakan sexual abuse yang masih dalam hubungan darah, menjadi bagian dalam keluarga inti. Seseorang yang menjadi pengganti orang tua, misalnya ayah tiri, atau kekasih, termasuk dalam pengertian incest. Kategori incest dalam keluarga dan mengaitkan dengan kekerasan pada anak.

2) Extrafamilial Abuse

Extrafamilial Abuse, dilakukan oleh orang lain di luar keluarga korban.

\section{Faktor-faktor apa yang menyebabkan terjadinya kekerasan terhadap perempuan dan anak dalam keluarga.}

Faktor Penyebab Terjadinya Kekerasan Dalam Rumah Tangga Faktor ekonomi merupakan faktor yang paling sering diungkap oleh informan. Tingginya kebutuhan rumah tangga dan tuntutan gaya hidup hedonis, serta rendahnya kemampuan suami sebagai kepala rumah tangga memenuhinya menjadi stresor tersendiri yang memicu terjadinya kekerasan .

Dari pernyataan di atas dapat ditarik analisis makna yaitu faktor utama penyebab terjadinya kekerasan pada korban kekerasan yang dtangani
P2TP2A adalah masalah ekonomi akan tetapi ada pula faktor lain yang dapat menjadi penyebab diantaranya kebiasaan buruk seperti mabukmabukan, perselingkuhan dan kekuasaan suami terhadap istri atau korban.

Telah disebutkan sebelumnya bahwa perilaku penyimpangan dapat dikategorikan ke dalam bentuk kejahatan. Untuk mengetahui faktor pendorong atau penyebab seseorang melakukan kejahatan, kita tinjau halhal yang terdapat kriminologi. Karena menurut Sutherland and Cressey, Kriminologi adalah himpunan pengetahuan mengenai kejahatan sebagai gejala masyarakat. Yang termasuk ke dalam ruang lingkupnya adalah proses pembuatan perundangundangan, pelanggaran perundangundangan dan rekasi-reaksi terhadap pelanggaran tersebut.

Telah disebutkan bahwa ketiga mazhab tersebut menganut teori determinisme, yang mengemukakan bahwa seseorang melakukan kejahatanditentukan(determine)oleh pengaruh luar atau lingkungannya, sedangkan menurut teori indeterminisme, kehendak seseorang untuk melakukan kejahatan itu dikendalikan oleh kemauan sendiri dan tidak dipengaruhi oleh faktor luar.

Dengan demikian faktor pendorong terjadinya kekerasan dalam rumah tangga, dapat disebabkan 
oleh adanya berbagai faktor tersebut. Artinya dapat dipengaruhi oleh faktor dari luar atau lingkungan, tetapi dapat juga dipicu karena adanya faktor dari dalam diri pelaku sendiri. Hal ini dapat diperoleh dari kasus-kasus yang pernah terjadi dan ditangani oleh lembaga-lembaga bantuan hukum.

Menurut LBH APIK, sebuah lembaga bantuan hukum untuk perempuan dan keluarga, penyebab terjadinya kekerasan dalam rumah tangga dapat digolongkan menjadi 2 faktor, yaitu faktor internal dan eksternal. Faktor internal menyangut kepribadian dari pelakuk kekerasan yang mneyebabkan ia mudah sekali melakukan tindak kekerasan bila menghadapi situasi yang menimbulkan kemarahan atau frustasi. Kepribadian yang agresif biasanya dibentuk melalui interasksi dalam kelaurga atau dengan lingkungan sosial di masa kanakkanak. Tidaklah mengherankan bila kekerasan biasanya bersifat turuntemurun,sebab anak-anakakanbelajar tentang bagaimana akan berhadapan dengan lingkungan dari orang tuanya. Apabila tindak kekerasan mewarnai kehidupan sebuah keluarga, kemungkinan besar anak-anak mereka akan mengalami hal yang sama setelah mereka menikah nanti. Ini disebabkan mereka menganggap bahwa kekerasan merupakan hal yang wajar atau mereka dianggap gagal kalau tidak mengulang pola kekerasan tersebut. Perasaan kesal dan marah terhadap orang tua yang selam ini berusaha ditahan, akhirnya akan muncul menjadi tindak kekerasan terhadap istri, suami atau anak-anak.

3. Aktor-aktor utama (pelaku
utama) kekerasan perempuan dan Anak Serta relasinya dengan para korban.

\begin{tabular}{|l|l|l|}
\hline Keterangan & $\begin{array}{l}\text { Delik } \\
\text { Biasa }\end{array}$ & $\begin{array}{l}\text { Kekerasan } \\
\text { dalam Rumah } \\
\text { Tangga }\end{array}$ \\
\hline Pelaku & $\begin{array}{l}\text { Semua } \\
\text { orang dari } \\
\text { segala } \\
\text { usia }\end{array}$ & $\begin{array}{l}\text { Suami, istri, orang } \\
\text { tua }\end{array}$ \\
\hline $\begin{array}{l}\text { Hubungan pelaku } \\
\text { dan korban }\end{array}$ & $\begin{array}{l}\text { Tidak } \\
\text { dikenal } \\
\text { Kenal } \\
\text { (tidak } \\
\text { ada } \\
\text { ikatan) }\end{array}$ & $\begin{array}{l}\text { Punya ikatan } \\
\text { karena } \\
\text { Perkawinan } \\
\text { Hubungan darah } \\
\text { Hubungan } \\
\text { pekerjaan }\end{array}$ \\
\hline Korban & $\begin{array}{l}\text { Bisa siapa } \\
\text { saja }\end{array}$ & $\begin{array}{l}\text { Istri } \\
\text { Anak, } \\
\text { kemenakan, adik } \\
\text { pembantu }\end{array}$ \\
\hline
\end{tabular}

Tabel di atas menunjukkan perbedaan antara delik biasa dengan kekerasan dalam rumah tangga. Sebetulnya bentuk-bentuk tindakan pidana pada umumnya dalam misalnya penganiayaan yang diatur dalam Pasal 351 KUHP, pembunuhan (Pasal 338 KUHP), pemerkosaan (Pasal 285 KUHP) dan penghinaan (Pasal 310 KUHP), perzinaan (Pasal 284 KUHP) dan perbuatan-perbuatan lain yang dapat dikategorikan 
perbuatan pidana yang diatur dalam Kitab Undang-Undang Hukum Pidana. Namun, kekerasan dalam rumah tangga mempunyai sifat yang khusus dan karakteristik yagn terletak pada hubungan antara pelkau dan korban, locus delicti-nya serta caracara penyelesainnya.

\section{Penderitaan Korban}

Seperti halnya dalam setiap perbuatan pidana (delik) selalu terdapat dua pihak yaitu pihak pelaku dan korban. Dalam hal ini yang sangat menderita adalah korban. Penderitaan korban seringkali luput dari perhatian, baik dari petugas maupun dari masyrakat. Karena seringkali korban menjadi korban ganda, yaitu mulai harus menceritakan kembali kasus yang menimpanya, sampai di ruang persidangan. Bagaimanpun juga dengan keharusan korban untuk menceritakan kembali secara berulang-ulang tentang kejahatan yang menimpanya, membuat korban merasa tertekan. Seperti yang diceritakan oleh seorang responden, mengulang-ulang tentang kejahatan yang menimpanya, membuat korban merasa tertekan. Seperti yang diceritakan oleh seorang responden, mengulang-ulang kejahtan yang dialaminya membuat korban justru tidak dapat melupakan peristiwa yang dialami. Belum lagi pada saat sidang di pengadilan, korban harus berhadapan dengan pelaku. Rasa marah, dendam, dan malu menjadi satu. Oleh karena itu, perlu ada pendampingan bagi korban sejak korban melaporkan kejahatan yang menimpanya.

Tidak dapat dipungkiri dalam setiaptindakpidanakorbanmengalami kerugian berupa kerugian materiil dan immateriil. Kerugian materiil berupa kehilangan barang-barang yang menjadi milik korban. Kerugian ini lebih bersifat ekonomis/mempunyai nilai ekonomis, sedangkan kerugian immateriil bersifat psikis/mental. Hal ini berkaitan kondisi kejiwaan korban. Kalau korban tidak dapat segera melupakan perbuatan pidana yang menimpanya, akan menyebabkan gangguan kejiwaan, di mana untuk menyembuhkannya membutuhkan waktu yang cukup lama.

Selain kerugian materiil dan immateriil, korban juga mengalami penderitaan. Terbagi atas dua macam, yaitu penderitaan jangka pendek dan panjang. Penderitaan jangka pendek artinya suatu penderitaan yang dapat segera hilang dalam jangka waktu yang singkat. Korban segera bisa melupakan peristiwa yang dialaminya. Hal itu berbeda dengan pendertiaan jangka panjang. Penderitaan korban berlangsung berkepanjangan, bahan sampai menganggu segala aktivitas dan kesehatannya, baik kesehatan fisik mupun psikis.

Dalam sebuah wawancara dengan seorang psikiater (dokter jiwa) disebutkan jiwa atau mental 
seseroang bisa terganggu, karena mengalami tindak kekerasan. Berikut skema untuk memperjelas uraian:

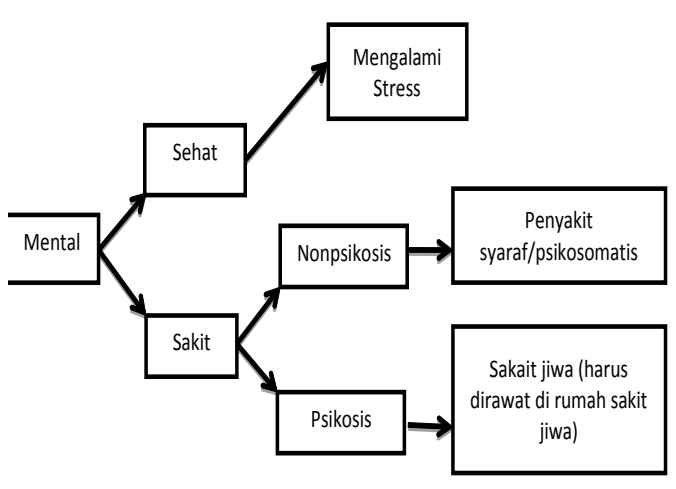

Penjelasan:

Mental/jiwa dibagi menjadi 2 (dua) bagia, yaitu mental sehat dan mental sakit. Mental sehat dapat mengalami stres, sedangkan mental yang sakit dibedakan menjadi dua (dua) yaitu nonpsikosis dan psikosis. Golongan nonpsikosis kebanyakan disebut sakit syaraf/psikosomatis, sedangkan golongan psikosis biasanya disebut sakit jiwa. Dalam keadaan ini harus dilakukan perawatan di rumah sakit jiwa.

Selanjutnya, mental yang sehat dapat mengalami stres yang diakibatkan oleh perbuatannya sendiri atau akibat tindak kekerasan dan tindakan-tindakan lain. Untuk mengenal manusia sebagai pribadi harus dilalui empat tahap, yaitu:
a. Biologis
b. Psikologis
c. Sosial budaya, dan

\section{d. Agama}

Empat tahap tersebut harus dilalui kalau kita ingin mengenal manusia. Kemudian dijelaskan bahwa proses perilaku manusia dimulai dari adanya stimulasi (rangsangan), kemudian ada motivasi (dorongan). Dari adanya dorongan dilakukan mobilisasi, sehingga mengakibatkan adanya perbuatan (aksi). Stimulasi bisa datang dari diri sendiri maupun dari luar. Misalnya seseorang yang akan melakukan tindak kekerasan, terlebih dahulu dia mendapat stimulasi (ransangan), mungkin dari kesalahpahaman, kemudian terjadi pertengkaran yang akhirnya diikuti dengan tindakan kekerasan.

Demikian pula kekerasan dalam rumah tangga tentunya mengakibatkan penderitaan yang dalam bagi korban. Hal ini tidak lepas dari apakah kekerasan dalam rumah tangga tersebut dilaporkan kepada polisis atau tidak. Penderitaan yang dialamiolehkorban dapatberlangsung lama, meskipun pelaku sudah mendapatkan sanksi. Dari beberapa responden diperoleh penjelasan bahwa penderitaan batin akibat kekerasan dalam rumah tangga, sulit dilupakan dan menimbulkan trauma psikologis. Hal ini berdampak pada kehidupan sosial dan perkembangan batin korban. Rasa kecewa yang sangat dalam seringkali membuat korban menjadi pribadi yang tertutup dan apatis. 


\section{E. Penutup}

Berdasarkan hasil pembahasan dari temuan data penelitian maka penelitian ini dapat disimpulkan:

1. Bentuk-bentuk kekerasan domestic terhadap perempuan dan anak yaitu:
a. Kekerasan Fisik.
b. Kekerasan fsikis
c. Kekerasan seksual
d. Kekerasan penelantaran
e. Kekerasan eksploitasi
f. Kekerasan trafficking, dll.

2. Faktor-faktor yang melatarbelakangi terjadinya kekerasan perempuan dan anak di Lombok Timur yaitu:

a. Masalah keuangan atau ekonomi;

b. Masalah anak;

c. Masalah cemburu;

d. Masalah saudara;

e. Masalah sopan santun;

f. Masalah masa lalu;

g. Salah paham;

h. Mau menang sendiri;

i. Tidak dapat menahan nafsu dan emosi j. Mabuk

k. Ada wanita atau laki-laki lain (WIL dan WIL)

1. Masalah orang tua, dll.

3. Hubungan atau relasi antara korban dengan pelaku ketika kekerasan itu terjadi yaitu lebih banyak dilakukan orang-orang terdekat atau dilingkungan keluarga, seperti suami istri, orang tua serta kelurga lannya.

4. Perlindungan terhadap perempuan dan anak korban tindak pidana kekerasan di Lombok Timur dilakukan oleh P2TP2A melalui jejaring kerjasama, yang berbentuk:

a. Pelayanan pengaduan;

b. Pelayanan medis;

c. Pelayanan medikolegal untuk kepentingan pembuktian di bidang hukum;

d. Pelayanan bantuan hukum;

e. Pelayanan kemandirian atau pemberdayaan;

f. Pelayanan rehabilitasi sosial. 


\section{DAFTAR PUSTAKA}

Abu Huraerah, Kekerasan Terhadap Anak, Cet. Ke 3, Nuansa Cendekia, 2012.

Syanne Cornelia Amalia Lay, Perlindungan Terhadap Anak Sebagai Korban Kekerasan Dalam Rumah Tangga, tt: YY,2008

Lilik Muladi, Kapita Selekta Hukum Pidana Kriminologi dan Viktimologi ( PT.Djambatan: Jakarta, 2004/2007).

Frans Magnis Suseno, Etika Politik (Prinsip-prinsip Moral Dasar Kenegaraan Modern), Jakarta:PT. Gramedia Pustaka Utama, 1994

Makalah pada Seminar Nasional "Perlindungan HAM dalam Proses Peradilan Pidana" dalam Barda Nawawi Arief, Beberapa Aspek Kebijakan Penegakan dan Pengembangan Hukum Pidana Bandung:Citra Aditya Bakti, 1998

Muladi, Kapita Selekta Sistem Peradilan Pidana , Semarang;UNDIP, 1995.

Mansour Fakih, Analisis Gender dan Transformasi Sosial, Yogyakarta:tt, 1999.

Abu Huraerah, Kekerasan Terhadap Anak, Cet. Ke 3, Nuansa Cendekia, 2012.

Bagong Suyanto dan Sri Sanituti Hariadi, Krisis dan Childs Abuse ( Surabaya: Airlangga University Press, 2002.
T.O. Ihromi, Bunga Rampai Sosiologi Keluarga,Jakarta: Yayasan Obor Indonesia, 2004.

Jurnal LBH APIK Tentang Kekerasan Perempuan dan Anak, 2003.

Moerti Hadiati Soeroso, Kekerasan Dalam Rumah Tangga, Perspektif Viktimologis dan Kriminologis, Surabaya; Sinar Grafika, 2004. Anne Grant, Domestic Violence, Abuse, and Child Custody: Legal Strategies and Policy Issues, ed. Mo Therese Hannah, PhD, and Barry Goldstein JD Civic Research Institute, 2010.

Bagong Suyanto, Tindak kekerasan Terhadap Anak: Masalah dan Upaya Pemantauannya, Surabaya: Kerjasama LPA Jatim dan UNICEF, 2000.

Koesparmono Irsan, Peran Polisi Dalam Perlindungan hukum bagi Wanita, Makalah dalam Lokakarya Hak Permpuan dan PenegakanHukum (Hotel Radison, Yogyakarta, 2526 Oktober 2001).

Djam'an Satori, Metode Penelitian Kualitatif , Bandung: Alvabeta, 2014

Rianto adi, Metode Penelitian Sosial dan Hukum, Granit: Jakarta, 2000

Lilik Muladi, Kapita Selekta Hukum Pidana Kriminologi dan Viktimologi PT.Djambatan: Jakarta, 2004 / 2007).

Kitab Undang-undang Hukum Pidana 
Undang-undang No. 23 tahun 1992

Undang- undang No 23 tahun 2000

UndangNomor23 Tahun2004tentang Penghapusan KekerasanDalam Rumah Tangga.

Undang-Undang Nomor 13 Tahun 2006 tentang Perlindungan Saksi dan Korban.

Deklarasi PBB Tentang Penghapusan Kekerasan Perempuan dan Anak.

Perda Kabupaten Lombok Timur No. 9 tahun 2013 Tentang Perlindungan Korban.
Kamus Besar Bahasa Indonesia, Departemen Pendidikan dan Kebudayaan, Jakarta:Balai Pustaka, 1989

Peraturan Pemerintah Republik Indonesia No. 2 Tahun 2002, Tentang Tata Cara Perlindungan Terhadap Korban dan Saksi Dalam Pelanggaran Hak Asasi Manusia Yang berat.

http:// radartegal.com/ beritakriminal/ayah-gilaperkosa-anak-kandungnyadulu-lalu.4086.html(sabtu, $\quad 16$ juli 2016.11:29). 